\title{
GUNNAR INTERNATIONAL
}

- la revue de luxe,

la plus chere du monde

\section{Bodil Marie Thomsen}

Gunnar International er et særpræget modeblad. Det er stort og uhåndtérligt $(33,5 \mathrm{~cm} . \times 48,5 \mathrm{~cm}$.$) , tungt (2$ $\mathrm{kg}$ ) og dyrt (100 Fr. eller $168 \mathrm{~d}$. kr.), men det er prangende flot!

Farverne på forsidernes kvindeportrætter er altid smukt afstemte, og her som i resten af bladet er de blanke og glatte sider af en fornem papirkvalitet, der minutiøst gengiver hver kornet detalje og dybde i billederne. Bladet består af billeder, billeder, billeder. Størsteparten af bladets stof udgøres af sort/hvide modelfotografier af tøj- og hårmode (fotograferet af Gunnar Larsen og assisterende fotografer). Store farvereproduktioner af aktuelle kunstneres malerier (fortrinsvist indenfor genrerne surrealisme, naivisme og science-fiction) blander sig tilfældigt med motestoffet. Den sidste billedandel er reklamer i alle mulige varianter, klassiske reklamer for f.eks. whisky, $\varnothing \mathrm{l}$ og mineralvand eller reklamer kamouflerede som modereportager, uden firmanavn og telefonnummer (1).

Bladet har ingen redaktionel leder. Tekstmassen er i forhold til billedernes skærmkaraktér (et opslag er på størrelse med de største tv-skærme) forsvindende lịlle. 
Typerne er små og tynde og ofte svære at skelnè i farveudskilningerne. Teksten, bogstaverne, ordene, sætningerne har nærmest illustrativ karakter på linie med billederne. Dette understreges i lay-out'en, hvor tekst og billeder (f.eks. i temareportagen, News pour les Hommes)) hver $i$ sin indramning er strøet ud over siderne, tematisk vidt forskellige men alene adlydende æstetiske love for tyngde-, skygge- og lysvirkninger.

Bladet er først og fremmest et visuelt organ for modetendenser, som det er redaktionens erklærede hensigt ikke blot at gengive, men $i \mathrm{~h} \varnothing j$ grad at kreere fotografisk videre på og fortolke billedæstetisk (2). Fotograferne iscenesætter tøj- og hårmoden dramatisk med lys- og skyggeeffekter, omgiver modellerne med traderede symboler (kranier, kæder, piske, læderantræk, hvidkalkede ansigtsmasker og lignende) for lidelse, død og seksualitet, retoucherer eller forstærker delelementer i billedet - og opnår i det færdige foto, når det lykkes, et fuldt synligt, gennemlyst fixérbillede, der $i$ sin fuldendte form giver moden et ekstraheret 'liv' tilbage.

Det er i fotografiets assimilering med kunstens produktionsformer, at det kan give moden dette 'liv': et liv som fetich, genspejlet i den fotografisk/kunstneriske gennemæsteticering af modens eget ideelle grundlag den perfekte model, det tilhører siảvel livets som dødens universer. Set med fotografens ideelle blik (linse) kan enhver genstand indgives dette 'liv' som fetich - den mest perfekte, lukkede form, som netop af den grund ikke virker foruroligende men tiltrækker sig opmærksomheden.

Alle Gunnar Larsens billeder spiller på feticheringen af modens visuelle strøm, og gennem den kunstneriske perfektionering skifter modens 'døde liv' opholdssted fra mannequin'ens formede krop til det kunstnerisk formede fotografi. Således bliver bladet, Gunnar International, selv. en skøn fetich og mere moderne end moden, fordi den er i stand til at fixere og samtidig levendegøre moden $i$ et overordnet fetichistisk blik, som moden indladende og æggende hele tiden søger at appellere til. Ingen mode bliver mode, før den er blevet set med et blik eller en linse - eller rettere: modens skin af nyhed ligger i det æsteticerende og formgivende blik.

Moden skabes $i$ vore dage ikke primært $i$ et spil mellem tøjets tilsløring og afsløring af kroppen, men 112 $i$ et gensidigt forførende visuelt spil mellem den seende og det sete. Det indfangende, stirrende blik afslører, hvad det vækseende, nedslåede øje forsøger at tilsløre, og samtidig er enhver tilsløring et tilbud om afsløring og enhver afsløring også en tilsløring.

Dét, at den nye mode afbildes, skaber (og afvikler måske også) i en vis forstand moden $i$ et sekundagtigt $\mathrm{nu}$, og det er derfor af mindre betydning, hvordan modesæsonens idealform 'tager sig ud' som 'objekt' på billederne. Vigtigere er det, at moden overhovedet afbildes, for afbildningen sætter en foreløbig visuel formgivning (et perspektiv) på den uophørlige relation mellem den seende og det sete.

Mode- og reklamefotos er gøglebilleder, simulakrer, som ikke har nogen reference udenfor sig selv. Derfor vokser formkravet til modefotografiet eksplosivt i disse år, hvor modens egen evne til form imploderer med mængden af 'nye moder'.

Dén fotografiets indbyggede fetichering af moden/modellen, som vi har kendt siden de første modefotografier, får altså i dag og også hos Gunnar Larsen en ekstra dimension. Gengivelsen af det absolutte øjeblik - nuet - forlænges i denne iscenesættelse, så vi ikke blot præsenteres for en standsning af tiden uden også for en tømning af tiden - tilbage står de absolutte simulakrer, fyldt med overdimensionerede, mytiske tegn. Tegn, der tilhører både fortid og fremtid, men som her står stille $i$ en reversibel tid, om hvilken alt og intet kan siges. Se illustration 1 !

\section{ALT OG INTET}

- døden, den sorte engel, natten...

Billedet (3), der er sort/hvidt, er kreeret over den danske designer Jean Voigts modekreationer og ledsages: af følgende tekst: "LA MORT, L'ANGE NOIR, LA NUIT...Det er en vis opfattelse af døden, næsten apokalyptisk, og af skønhed indskrevet i skyggen af disse kreationer, hvis ophavsmand er den berømte kreatør Jean Voigt. Det er disse prægtige og üramatiske aftenkjoler, der har været inspirationskilde til billederne heroverfor." 


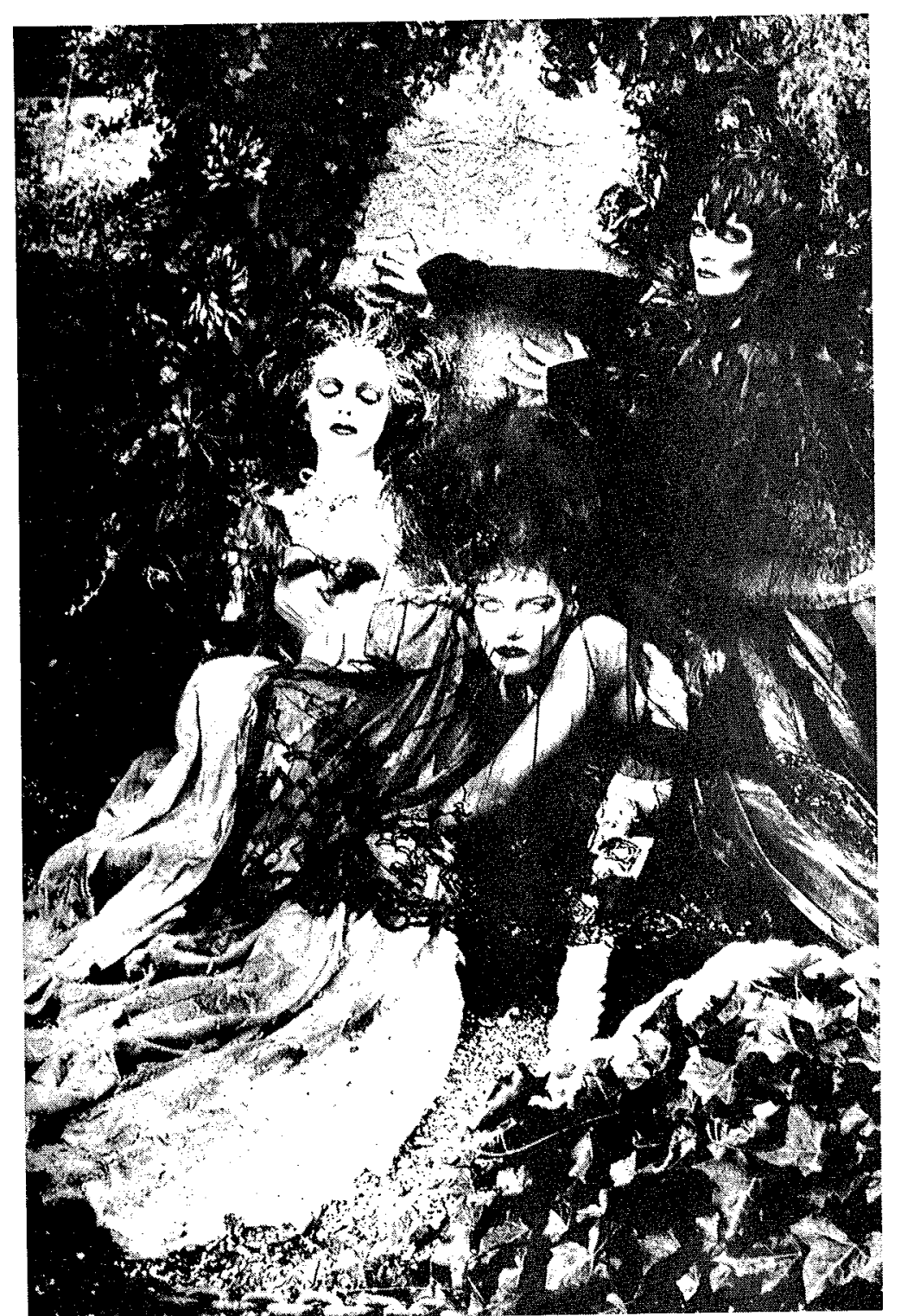

Illustration 1
Tøjet, folderne, stofferne giver materiale til lugte, føleog synssansen. Den bløde velour, den blanke satin, den smygende silke, den glatte nylon, de kildrende fjer, det stride hår, de skarpe negle blander sig med den tunge duft, man aner fra blomsterne, de krøllede blade, den våde grus og den fugtige sten. Og øjnene stirrer dæmonisk frem fra de kraniumstomme øjenhuler. Natur/kultur, levende/død, dæmon/engel alt sammen i det samme billedplan. Stenens indridsninger afdækkes og skjules i samme bevægelse, ansigtsmaskernes øjne stirrer camoufleret af sminken ud mod os.

De analytiske koder: bøddel/offer, seksualitet/død og jomfru/heks/engel tilbyder sig blasfemisk i billedet for analytikeren.

Fra venstre kan vi uden større anstrengelse interpretere modellerne som voldtaget, død, jomfru, - fordømmende, isnende heks, og nederst - overjordisk, dødbringende engel.

Endvidere kan vi forføres til en videre interpretation af modellens (kvindens) status i modens univers: omkranset af kæden, den urørlige zone, - fra indridsning til indridsning den levende, døde kvinde, - imaginaritetens fantomer mellem dyr og menneske, - korsfæstet, død og begravet... og opstanden i modens evige cyklus.

Kort sagt: en sådan analyse duer ikke. Den er alt og intet - den er selv blevet transportmiddel for tomme simulakrer, der $i$ en ubrudt strøm af spejlinger kan gengive alt, hvad der rører sig af symboliseret vraggods i kulturens overflade. Læserens indskrift er på forhånd programmeret ind $i$ billedets blanke flade $i$ form af stivnede metaforer, håndfaste symboler og citater. Og "medierne tætner som en spejlblank himmel over vore hoveder, drømmeteknologien absorberer alt, hvad der rører sig, og sender det programmeret tilbage som en hånlig parodi. Var det dét, du drømte, eller dét, eller dét? Alt er muligt, undtagen forandring." (4)

Er vi som læsere, analytikere så også henvist til den blotte gengivelse: dét siger billedet, og dét, og dét, eller til blct at kunne konstatere, at billledet har simulakrekaraktér?

Hidtil har vi kun beskæftiget os med billedets umiddelbare associationsfelt, dets sætten sig i spil og i scene med vore egne menings- og indholdstilskrivninger. Men 
ser vi bort fra disse tilskrivninger, - så har vi 3 modeller, iført Jean Voigts tøj, stående, sidddende og liggende pá en grav. Billedet har tre (rumlige) niveauer, der udgøres af 1) forgrunden, som markerer det rumlige niveau for betragterens blik, 2) modellerne i centrum og 3) gravstenen, der 'lukker' billedet i baggrunden.

Umiddelbart vil vi antage, at billedets "budskab" ligger i det 2.niveau, og det er den ovenstående læsning udtryk for. Ser vi derimod nærmere på de visuelle linier, der er nedlagt i billledets opbygning, viser det sig, at det er i spillet mellem 1. og 3. niveau, at 2.niveaus betydning skabes:
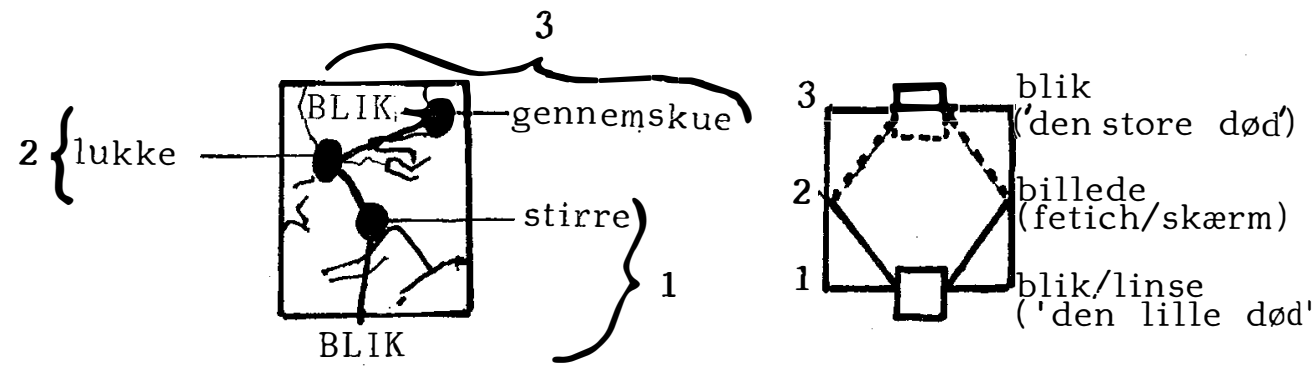

Går vi ud fra fotografens/læserens blik på sceneriet i linsens hhv. bladets spejl, reflekteres vore blikke af den nærmeste models genspejling af vor nidstirren, dernæst af den midterste models nedslåede blik og endelig af den bagerste models gennemskuende blik. Alle lukker de af for vore blikke. Blikliniens zig-zag ender - forlænget af den bagerste models armstilling - i gravstenens gråhvide flade. Den nærmeste model iklæder sig blikket fra forgrundens l.niveau ligesom den fjerneste model symbolsk fremstiller dødens fatale gengældelsesblik i 3 . niveau. Den midterste model unddrager sig blikduellen, repræsenterende det fuldt synlige billede, dén modens skærm, der som en lukket fetich drager blikkene til sig (5).

Her, fra det fraværende blik, udgår modens fascinationskraft. Men vi må ikke glemme, at det er blikkene, der skaber feticheringen og at billedets 'budskab' ligger indlejret i blikrelationerne. Således bliver læserens blik på billedet nødvendigvis ligeså fetichistisk som fotograf- ens, hvis denne overhovedet skal have mulighed for at 'se' billedet. Og det er læserens 'indblik' i billedet, der i sidste instans levendegør' billedet, dvs. moden.

Fotografens blik (klik) skaber en standsning i og med billedet, og punktet, som hans blik udgår fra, er nedlagt... i billedets perspektiv. Når læseren træder ind på denne plads, ser hun nok de samme genstande som fotografen (modeller, kjoler, gravsten). Men $i$ og med, at den visuelle operation nu er en aflæsning, levendegøres billedet via blikrelationerne (læseren møder så at sige fotografens blik), og genstandene kan dernæst imagineres og gestaltes med læserens kulturelle koder. Det døde (billedet) og det, fotografen har 'dødet' med sit blik (her moden) bliver altså levende for læseren.

Det er i mødet mellem et fraværende blik (fotografens, som er bevaret i motivets stivnen til billede) og læserens blik, at billedet bliver "levende". Først derefter skabes motivets betydning. Hvad det afbildede forestiller er mindre væsentligt end at det forestiller.

Stillet overfor billedet af Jean Voigts kreationer, hvor Gunnar Larsen, som han ofte gør det, har valgt såvel at overpointere blikrelationernes fatale karakter som at forstørre modellernes gestaltninger som rene modesimulakrer, bliver en tolkning dobbelttydig.

Er man først opmærksom på blikrelationernes konstituering af billedet, bliver de fetichistiske træk i billedet som nævnt meget tydelige - så tydelige, at læseren næsten selv mærker, hvorledes blikket bliver stirrende, når det fortabes i billedfetich'en. Men er blikrelationen først aflæst, giver netop Gunnar Larsen 'forstørrede' billeder adgang til at se modens æstetiske koder og symbolernes simulakrekaraktěr.

I dette billede møder vi tre mulige strategier, som moden tilbyder overfor fotografens dødbringende blik (standsning af bevægelsen). 1) Det isnende, kolde blik, der dæmonisk/forstenende kaster blikkene tilba'ge, hvor de kom fra - symbolsk iklædning: medusakvinde.

2) De lukkede øjne, der til gengæld tilbyder kroppen som urørligt/mangfoldigt objekt for blikkene - iført 'afmægtigheden' hos såvel jomfruen som luderen og liget.

3) Det vedholdende, gennemskuende skæve blik ifønt dødsindlevelsen hos săvel heksen som melankolikeren. 
Alle disse blikke er kastrerende men samtidig selv iført forstenede simulakrer fra kunsthistoriens gallerier og modehistoriens garderobeskabe.

Sceneriet er, hvad motivet angår, overlæsset til det selvironiske, men morsomt er det ikke, ligeså lidt som stiletter, korsetter, pelsværk og de øvrige klassiske ingredienser i fetichistens lystbilleder er det. Alvoren holdes i skak af blikkene, der som sagt garanterer billedet dets fetichistiske dimension - og garanterer moden dén 'faste form', der alene kan kvalificere den ene mode fremfor den anden i dag.

Således kommer Gunnar Larsens kunstnerisk bearbejdede modefotos til at belyse nogle grundtræk (måske de væsentligste) ved såvel moden som modefascinationen.

Det er enhver ny modes aspiration at opholde sig $i$ et imaginært rum mellem bevægelse og stivnen, mellem tilskrivning og afskrivning. Enhver modenyhed postulerer muigheden af et sådant rum hinsides eller før det symbolske betydningslag. Og modefascinationen ligger tilsvarende $i$ det at se det endnu ikke tilvante $i$ en form, hvor det hverken skræmmer eller hæmmer de imaginære billeddannelser (6).

Det, der skabes, de nye moders skønne skin af 'nyhed', skabes i fetich'ens form, som langsomt mister sin glans, efterhånden som den 'synker ned' i hierarkiet fra Haute Couture til Prêt-à-porter til varehuset og ender hos forbrugeren. Modeforbrugerens $\mathrm{k} \varnothing \mathrm{b}$ begrunder sig $i$ en stadig søgen efter en mediering af dødens (det absoluttes, fatalitetens) vilkår på den ene side og tilværelsens til kedsomhed grænsende afkvalificerede tid på den anden.

Moden tilbyder et imaginært spejlbillede i stedet for den amputerende og kastrerende adgang til den symbolske orden, og fixeringen af det smukke, fuldendte,perfekte og bestandigt samme (spejl)billede holder døden på afstand, netop fordi den inkorporeres i moden. Muligheden for den stadige billedgennemstrømning mellem det symbolske og det reelle er givet med feticheringen af moden i bestandigt nye former.

FUTURISMENS REDDENDE BLIK. (Se illustration 2)

Billedet, le regard sauvage du futurisme, reklamerer for en hårkunstner, Marianne Gray, og en make-up kunstner, Armelle Leon, som, med en "skør frisure" og en sminkning á la "forskrækket kat", i fællesskab har transformeret modellen, Lotte Heise, til "noget fremmed og ukendt, som om det kom fra en anden verden." (7)

Næsen, halsen og hagen er næsten fuldstændig bortretoucherede. Munden er billedets center, som formidler krydsrelationen mellem de mørke hænder i billedets forgrund og de mørke øjne i billedets baggrund. Billedet virker foruroligende dynamisk. Er det fordi hænderne, der uhyggeligt truende rejser sig i billedets nederste kant, om lidt vil omslutte offerets hals? Nej, bøddelhænder er det ikke. Det er modellens egne hænder/katteklør, der ikke, som forventet, vender ud mod læseren men nærmest skærmende ind mod modellen selv. Men hvorfor er de krogede, (selv)dstruktive?

I modellens blik møder vi hverken en dæmonisk, stirrende eller lukket genspejling. Blikket er sorgfuldt, melankolsk, men fortroligt, indifferent forskende uden dom. - Nærmest som vi møder vort eget blik i spejlet eller en kær vens eller en mors. Her mødes vort blik endelig med an andens uden stirren eller undvigelse. Her kan øjnene falde til ro $i$ en udveksling, der giver os en berettigelse - men kun, hvis vi ser bort fra hænderne, der udgør spærringen, kastrationen af den livgivende (blik)relation. En sammensmeltning er ikke mulig. Hun (blikket) er og bliver uopnåeligt. Hun er imago, fetich, overjordisk og hellig. Spærringen ligger mellem vores og hendes blik. Billedets blikrelationer kan tolkes på 2 måder:

MODEL I

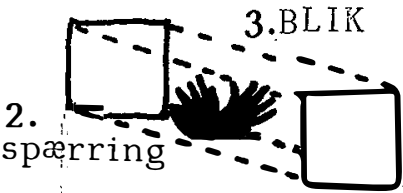
-BL IK

\section{MOODEL II}

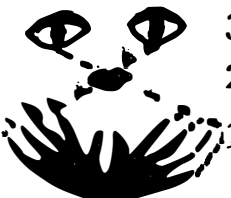

3. BLIK

. genopretning

BLIII.

Fragmentering af perspektivet 


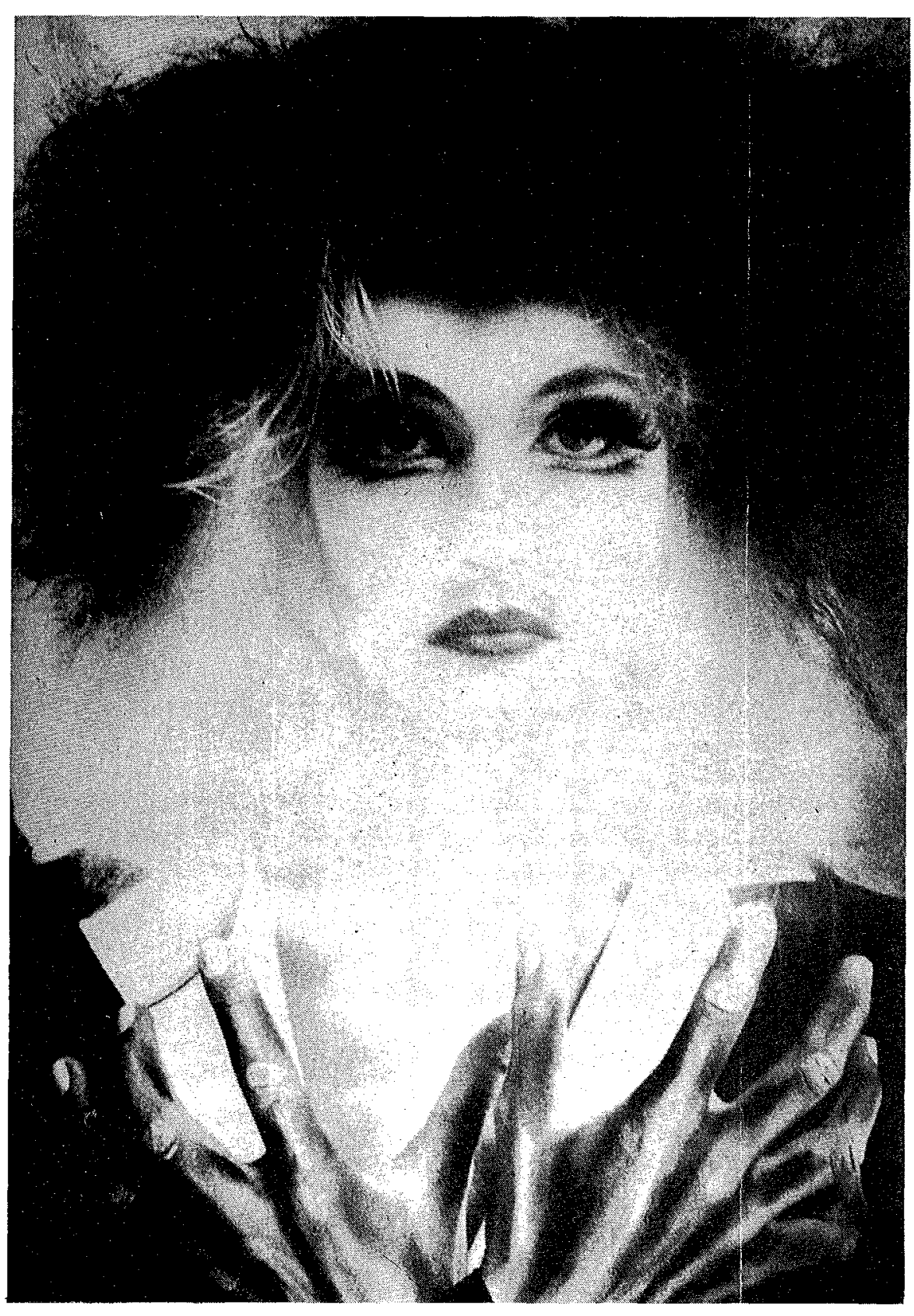

illustration 2

120
Ifølge model I ser vi direkte ind $i$ modellens $\varnothing j n e$ som $i$ et spejl. Udvekslingen hindres af de spærrende hænder, der som et fremmedelement destruerer muligheden for at nærme sig det livgivende imago. Ifølge model II udgår vort blik fra hænderne, så vort perspektiv allerede i udgangspostionen er fragmenteret. Gennem mundens center genoprettes det visuelle perspektiv, men kun, hvis vi ser billledet nedefra ligesom forgangne tiders gudeafbildninger. Så først kan vi møde modens auratiske blik i uforstyrret harmoni. Billedet, en momentan forsoning af 'liv' og 'død' i øjnenes udvekslingsspil, har det destruktive/fragmenterende element indbygget uden hvilket, det ikke var muligt.

Billedet kan ses både som spejl og som gudebillede. Det væsentlige, at det er gennem blik-destruktionen modens fetich oprettes, er gyldig i begge læsninger. Uopnåeligheden, det overjordiske er derimod sikret, det feticherede objekt uskæmmet af begærlige, begramsende blikke - indsatsen er den perspektiviske distance, som skaber $\varnothing$ nsket om ind-levelse.

Hos Walter Benjamin var det den fremadskridende storm, der hindrede Angelus Novus i oprydningen af historiens ruinhob, i genopvækningen af de døde, - med udspændte vinger og opspærrede øjne kunne han kun være vidne til katastrofernes ruinhob i det forgangne.

I min tolkning af moden har vi fået rollen som et anråbende blik, placeret i ruinhoben. Modens fetich le regard sauvage du futurisme - er uopnåelig, umulig at fastholde, men må hele tiden genoprettes og gestaltes i nye, foreløbige udgaver. Den fuldendte, den perfekte afbilding krakelerer med realiseringen hver gang, vi tror at have opnået idealet - at være smukkest og mest moderne. Ruinerne hober sig op i klædeskabet, mens voredrømme påny genskaber mode( $r)$ idealet. Det må til gengæld som en forblæst engel hele tiden materialisere sig på grænsen til det symbolske, hvor det ikke kan få varigt ophold uden selv at forvandle sig til ruin.

Fotomodellernes perfekte look på billederne præsenterer sådanne drømmeengle, på grænsen mellem livet og døden. Ligesom gudebilleder både åbner og spærrer de for adgangen til lidenskabens grund: længslen efter skønhed. 


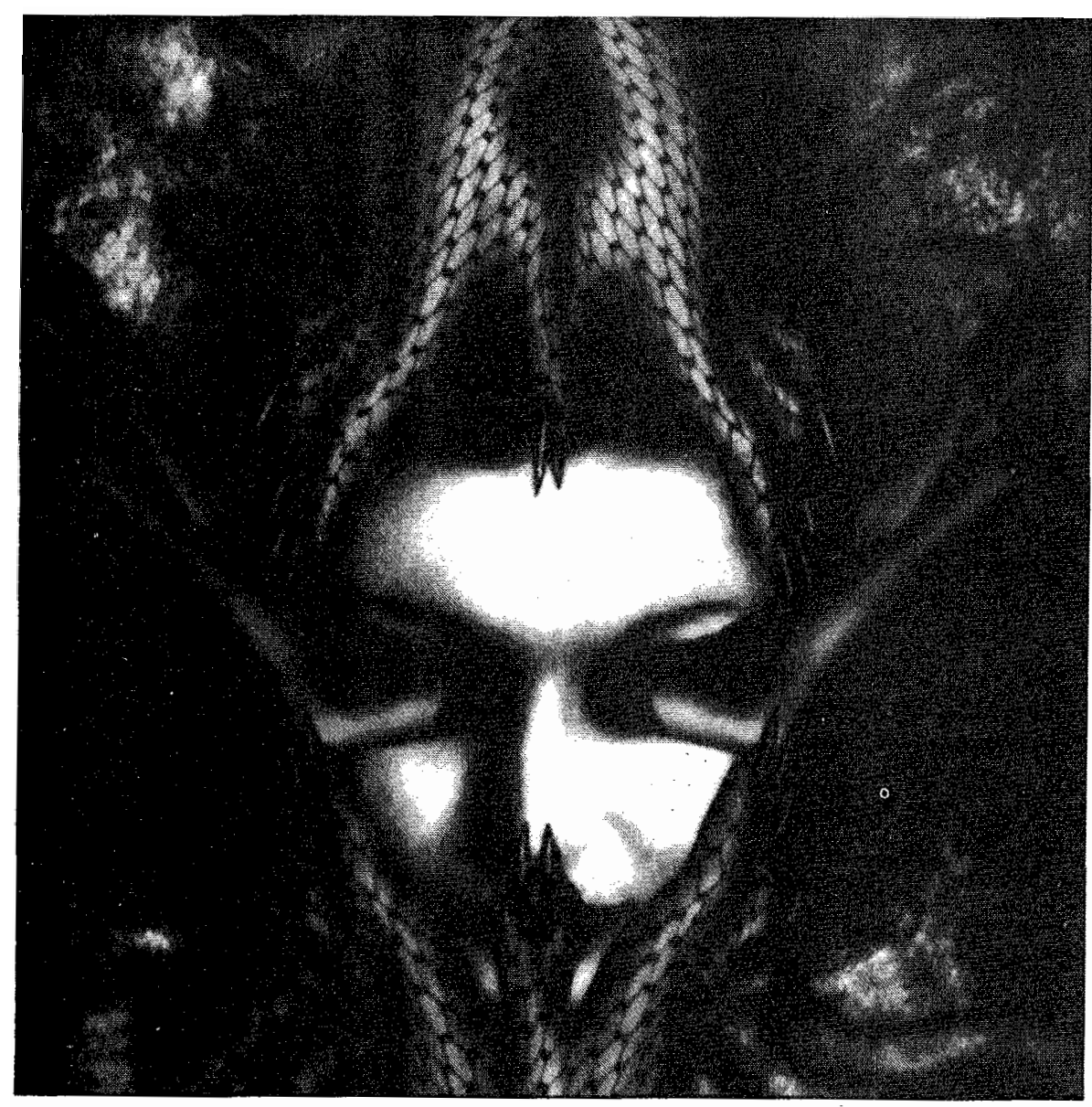

Illustration 3

\section{ANGELS NEVER CRY. (8)}

Gunnar Larsens billeder har en særlig, både 'lækker' og foruroligende skønhed. En skønhed, som fascinerer og forfører, fordi den forstørrer og 'oversætter' modens metonymiske forflygtigelser til håndfaste metaforer med klare visuelle konturer. En foruroligende skønhed, fordi Gunnar Larsen arbejder med simulakreformgivninger på et højt teknisk og visuelt reflekteret niveau, hvis fotografisk/historiske rødder måske kan spores tilbage til surrealismens skønhedsdiagnose: "Convulsive beauty will be erotic-veiled, explosive-fixed, magic-circumstantial or will not be at all". (9)

Mange modefotografer har før Gunnar Larsen forstået at indfange modens 'esprit', men Gunnar Larsen modellerer videre, fravrister moden en betydning, den ikke selv giver og forstår gennem billedfordoblingen og beherskelsen af den visuelle teknik at gøre moden til en vibrerende fetich: erotisk-sløret, eksplosiv-fikseret og magisk-omstændelig.

Hvorledes sammenhængen mellem vore dages modeog reklamebilleder og den surrealistiske tradition mere detaljeret tager sig ud, kunne det være spændende at undersøge - ikke mindst i lyset af de formeksperimenter, der finder sted indenfor såvel mode som kunst i disse år. (10)

Her vil jeg slutte med et billede fra Gunnar International (11). Se illustration 3 !

Gunnar Larsen får det sidste ord med følgende billedtekst:

"PIERRE MOLINIER

Maleren og fotografen Pierre Molinier, der døde for nogle ar siden, efterlod sig et ætsende og foruroligende værk helt i tråd med ånden hos den surrealistiske gruppe, han tilhørte. Pierre Molinier, som forblev i udkanten af denne, udviklede en kroppens fantasmatik i et enestående narcissistisk ritual. Obskøn og skandaløs er Pierre Molinier hele vejen igennem et værk bestående af teatralske sekvenser, hvor kroppen - hans egen forædles i tranvestismen og fetichismen ved spillet med masken, spejlet og fordoblingen..." 
NOTER:

1) Gunnar International er udkommet i 21 numre siden 1980 ca. 4 gange årligt. (Før (siden 1975) udgav Gunnar Larsen magasin'et Mode Avantgarde). Bladet, hvis redaktion består af 4 personer, sælges udover i Frankrig i Norge, Danmark, Holland, Belgien, Tyskland, Italien, Spanien, Canada, Amerika og Japan. Japan er den største aftager næst efter Frankrig. Eksportmarkedet alene udgør 7000 eksemplarer, som ved hvert nummers udgivelse transporteres pr. fly - vægt 14 tons.

2) Ifølge et telefoninterview med Gunnar Larsen d. 8/7 1986, ønskede redaktionen med bladet at opdyrke dén modefotografiske side, som Vogue ikke længere repræsenterer ("Det har udviklet sig til et telefonkatalog"). Og fordi bladet ikke tilhører en stor, træg koncern og ikke baserer sig på markedsanalyser ("Hvem vil købe et blad, der er en halv meter langt, vejer $2 \mathrm{~kg}$ og har det bizartlydende navn: Gunnar?"), kan det lade sig gøre at tiltrække sig interessen. Den stramme redaktionelle linie, focuseringen på det visuelle, inddragelsen af/samarbejdet med (ukendte) kunstnere har givet bonus - også overfor annoncørerne, som i starten var lidt usikre overfor denne lanceringsform. Nu har Gunnar International skabt en ny reklameeffekt: Har bladet udvalgt og gengivet ens design af modetøj og -hår, er det tegn på, at man tilhører den celebre klasse. Gunnars billeder udstilles $i$ forretningernes vinduer som et blåt stempel.

Gunnar Larsen betegner selv bladet som et "snobblad", man har liggende på kontorets sofabord, salonens bladhylde etc. for at vise, at man har, råd. Bladet spiller bevidst på det i titlen - la revue de luxe, la plus chere du monde - og dette mærke har den sammen funktion som krokodillerne på Lacoste-tøjet.

3) Gunnar International, nov., 83.

4) P. A. Brandt, Sky og Krystal, kbh. 1986, p. 23.

5) Om modefetichistens lidenskab kan man læse videre i P. B. Søndergaards artikel "Den indre Marlenes glansfulde glæde" og om blikrelationer i min artikel "Tilsløring og afsløring" $i$ bogen Slidser - en bog om mode, Århus 1986.

6) Julie Kristeva ser $i$ sin bog La révolution du langage poétique, Paris 1973, fetichistens bestræbelser som mere end perfektionering, en udfyldning af et (moder)imago, der skal holde stand mod kastrationen og derfor selv indskriver sig som fallos. Kristeva's tolkning åbner for en mere nuanceret begribelse af fetichen som en kontakt til både det semiotiske og det symbolske. Stasernes markeringer (rytmerne, bevægelserne mellem mor og barn) betydes $i$ grænsen til det symbolske og søges således placeret som erstatning for tegnet. Således kan også den kunstneriske praksis ses som et forsøg på at bibeholde den betydning, som lå før den symbolske ordens indstiftelse i subjektet - uden at det betyder, at kunstneren er fetichist. Kunstneren forsøger i og med betydningspraksis'en, som involverer splittelse og brud og afskæring fra det semiotiske, alligevel at være sensibel overfor de semiotiske betydninger (jnif. hendes egne analyser af bl. a. Mallarmé, samt I. Hassan, The Dismemberment of Orpheus, Wisconsin/London, 1982).

7) Gunnar International, nov., 83

8) Overskriften refererer til titlen på Gunnar Larsens sidste modeshow, der netop har tourneret i Skandinavien. Titlerne på de forgående var Angels and Devils in Future, Love, Hate and Fashion og den første, Dressed to Kill.

9) A. Bretons udsagn, citeret af Nadeau, The History of Surrealism, p. 250 - her citeret fra Hassan, op. cit. p. 76 .

10) Interessante perspektiver på såvel surrealisme (ved Mary Ann Caws) og fetichisme (ved Naomi Schor) i relation til kvindekroppen, -billederne og -litteraturen findes $i$ "The Female Body in. Western Culture", red. af Susan Robin Suleiman, 1986. Hos Naomi Schor lægges der specielt vægt på at se kvindelig fetichisme som en strategi til at bibeholde biseksualitetens muligheder. Hun ser forkærligheden til fetichen som en måde at opretholde vekselvirkningen mellem benægtelse og erkendelse af kastraktionen, som en måde for kvinder at drage fordel af "femininitetens gåde". Bruger man disse års modefascination som eksempel, bliver det med Sarah Kofman meget tydeligt, at "/en/ generaliseret fetichisme, defineret som en generaliseret vekselvirkning, /ikke/ udelukker en kvindelig fetichisme, eftersom det implicerer almengørelsen af "det kvindelige" og afslutningen på phallos' privelegium som fetich" (in S. Kofman: "La Cloche", in Philippe Lacoue-Labarthe et 
Jean-Luc Nancy (red): Les Fins de l'homme: A partir de Jacques Derrida, Paris (her citeret fra Naomi Schor op. cit.).

11) Gunnar International, april, 86.

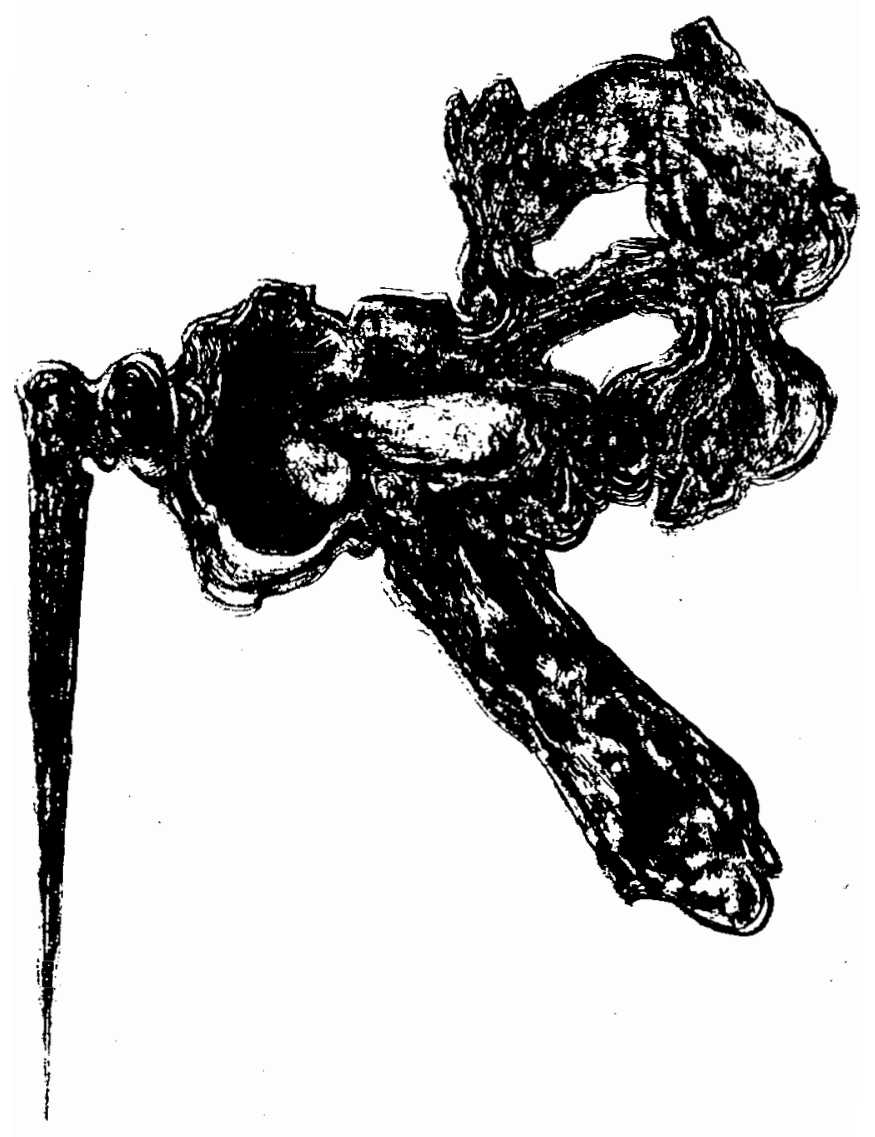

